\title{
States of sovereignty, sovereign states, and ethnic claims for international status
}

\author{
OLIVER P. RICHMOND ${ }^{1}$
}

\begin{abstract}
Sovereignty is heavily contested by existing states which view the survival of territorial sovereignty as vital to international order and many ethnic groups that see states as an obstacle to their own claims to sovereignty. This article looks at how and why ethnic claims to sovereignty arise. It examines when such claims may emerge, what forms such claims may take, the benefits ethnic groups perceive may accrue, and the implications for the international system and the emerging post-Westphalian international society.
\end{abstract}

'Sovereign, law, and prohibition formed a system of representation of power which was extended during the subsequent era by the theories of right: political theory has never ceased to be obsessed with the person of the Sovereign. Such theories still continue today to busy themselves with the problem of sovereignty. What we need... is a political philosophy that isn't erected around the problem of sovereignty, nor therefore around the problems of law and prohibition. We need to cut off the king's head: in political theory that has still to be done.'

'The paradigm of sovereignty operates on the basis of a simple dichotomy: sovereignty versus anarchy.'3

\section{Introduction}

Sovereignty has become inextricably associated with debates about power, territory and international status, and has been generally acknowledged to provide internal security in a Westphalian order which combats anarchy: yet in the case of ethnic groups' attempts to gain status and security this linkage is fundamentally flawed. 'Ethnic sovereignty' occurs when ethnic groups claim sovereignty and try to act as if they were sovereign at the military, political, social, and institutional levels. It is a form of quasi sovereignty constituting, perhaps, more than a degree of statehood. ${ }^{4}$

1 Thanks go to Costas Constantinou for his invaluable input during the evolution of this article. I am also indebted to Petra Roter for her careful comments.

2 M Foucault, 'Truth and Power', in Paul Rabinow (ed.), The Foucault Reader (Penguin, 1991), p. 63.

3 David Campbell, Writing Security (Manchester University Press, 1992) p. 72.

4 Numerous cases in recent history attest to the significance of this issue: Taiwan is perhaps the most co-ordinated of non-recognized states, Chechyna was until 1999-2000 the most successful against the weakened might of the Russian army; Palestine has moved closest to attaining international legitimacy akin to positive sovereignty; Republika Srpska illustrates the ambiguity that sovereignty currently implies, while Western Sahara illustrates the ambiguity which exists between statehood and independence. Insurgent movements are in effect 'quasi-states' as Clapham has pointed out. See Christopher Clapham, "Degrees of Statehood", in Review of International Studies, 24 (1998). See also Robert H. Jackson, Quasi-states: Sovereignty, International Relations and the Third World (Cambridge: Cambridge University Press, 1990), p. 150. 
Often the only resources such groups are denied are international relations, external legitimacy, and regional economic integration. Ethnic claims for sovereignty, often expressed through separatist violence, arise to prevent insecurity through irredentist or secessionist movements, inspired by grass roots movements, internal ethnic entrepreneurs, or by outside actors. Out of about seventy-five conclusive or inconclusive separatist conflicts since 1945, about fifteen have resulted in an apparent military victory for the state (including the recent case of Chechnya) and a further four are being contested; several have resulted in independence for the group (Bangladesh, Eritrea, Macedonia, Croatia, Slovenia, and possibly Slovakia and the Czech Republic); seven have been the recent subject of a devolutionary process (including Northern Ireland); six have been frozen and unresolved (including Cyprus); two have led to possible future statehood (Kosovo and East Timor); four have led to peace accords of a questionable nature; seven have resulted in peace accords and accommodation; a further ten have led to an accommodation contested by various factions; and at least thirteen are subject to ongoing violence (including the Kurds, in Kashmir, in Irian Jaya, the Tamils, in Southern Sudan, and the Punjab). At least forty-five states have been threatened with division, possibly several times, or have divided during this period. ${ }^{5}$

The exercise of ethnic sovereignty may lead to unsustainable non-pluralist entities whose internal legitimacy is probably far greater than their external legitimacy (as in the case of the TRNC). ${ }^{6}$ Ethnic groups may find themselves supporting authoritarian leaders who exploit forms of violence and who may not represent democratic ideals of civil society, as has been the case with Yasser Arafat, the leader of the Palestine Liberation Organisation, and with various Kurdish, Chechen, Tamil and Kosovan militants. The entities emerging from these struggles, by virtue of their mono-ethnic nature, are likely to become engaged in violent conflicts with the recognized states in which they are located, and, if they receive independence or autonomy, may find it far more difficult to enter into reciprocal arrangements with other actors in order to join interdependent economic and security groups. Yet they come into existence because national sovereignty produces exclusion for nonhomogenous identity groups through its concentration on the predominance of international security, its weakness in overseeing civil society (via a reliance on democratic structures that can create minorities within political minorities), and through the inherent structure of non-intervention which arises at the interstate level. This latter often fails to prevent such pressures on ethnic groups from arising, such that they, their neighbours, or their leadership, turn to violence in response (as recently seen in Kosovo) in the search for human rather than state security. Yet, paradoxically, human security is perceived to be provided by ethnic groups through state security in the international system. This has, since the end of the Cold War, raised the issue of humanitarian intervention; in turn, this has brought the practice of both peacekeeping and peacemaking beyond the limits that the norm of non-

\footnotetext{
5 See in particular Alexis Heraclides, 'The Ending of Unending Conflicts; Separatist Wars', Millennium, 26: 3 (1997), pp. 704-7. See also Alexis Heraclides, The Self-Determination of Minorities in International Politics (London: Frank Cass, 1991); Ted Robert Gurr and Barbara Harff, Ethnic Conflict in World Politics (Oxford: Westview Press, 1994); Ted Robert Gurr, Minorities at Risk: A Global View of Ethnopolitical Conflicts (Washington, DC: United States Institute of Peace Press, 1993).

6 The Turkish Republic of Northern Cyprus has high levels of internal legitimacy yet is completely dependent upon Turkey.
} 
intervention normally prescribed. Because this has generally occurred in the context of ethnic conflict, a normative discourse has re-emerged focusing on humanitarianism, culture and identity, and motivated by a need to regain 'order' and protect the status quo on the part of the dominant actors of the international system. Thus, ethnic claims to sovereignty have raised the issue of the identity of the international system and the question of on what normative, cultural, and political basis the international community can respond to such claims. There are three levels to explore here: the first relates to how states view ethnic sovereignty; the second relates to how ethnic groups view state sovereignty; and the third relates to how to the international community responds to such claims.

The following article elaborates on these points in an effort to uncover both the implications of universalizing sovereignty debates for ethnic actors and how the international system itself may provoke ethnic sovereignty. It addresses how and why ethnic sovereignty arises, and with what results. The construction of the notion of ethnic sovereignty is derived both from strategic considerations and the normative turn that has emerged relating to considerations of justice and security which permeate the international system, and which are increasingly problematic. ${ }^{7}$ Paradoxically, this turn, when applied by identity groups, threatens to reproduce the flawed Westphalian treatment of identity - something that the bulk of the literature on ethnic conflict seems to have ignored.

\section{Conflict and concurrence within international society}

The international system in the post Cold-War environment is rapidly evolving, incorporating interactions and transactions between many different actors, and involving different debates relating to power, sovereignty, intervention, norms, and resources of both a concrete and abstract level. There are three levels that can be identified and characterized in a general way from the point of view of the ethnic actor. $^{8}$ The first relates to the societal level and can be referred to as civil cooperative society made up of ethnic or multi-ethnic groups. The second refers to the level of the traditional interstate system in which inflexible norms of sovereignty exist relating to nation-states, and the third relates to the contradictory tensions caused by the parallel forces of regionalization, globalization, and identity (producing

\footnotetext{
7 Mervyn Frost, Ethics in International Relations (Cambridge: Cambridge University Press, 1996); David Held, Democracy and the Global Order (Cambridge: Polity Press, 1995); Emanuel Adler, 'Imagined Security Communities: Cognitive Regions in International Relations', Millennium, 26: 2 (1997); Nayef. H Samhat, 'International Regimes as Political Community', Millennium, 26: 2 (1997) provides an interesting account of the construction of ethical regimes.

8 These three levels draw on the levels of analysis framework generally used in the literature to discuss conflict and peacemaking. Several models have been used to break down conflict environments, notably Suganami's 'levels of-causation' model in his analysis of causes of war, and Ramsbotham and Woodhouse's 'dimensions-of-conflict' approach, which distinguishes structural, relational and cultural features. Here, I follow Miall, Woodhouse and Ramsbothom's usage of 'adapted levels-of-analysis' in my critical approach '... as it lays bare the complex and controversial relationships between international, state and societal sources of conflict, all of which are prominent in the recent literature and none of which is reducible to the others'. See Hugh Miall, Oliver Ramsbotham and Tom Woodhouse, Contemporary Conflict Resolution (Cambridge: Polity Press, 1999), pp. 77-8; See also H. Suganami, On The Causes of War (Oxford: Clarendon Press), 1996; Oliver Ramsbotham and Tom Woodhouse, Humanitarian Intervention in Contemporary Conflict (Cambridge: Polity Press, 1996).
} 
integration and fragmentation) that operate at a level where sovereignty is viewed as both reciprocal and inflexible, yet weakening. At this level, the much contested concepts of global civil ${ }^{9}$ and international society provide a framework for the humanitarian claims of actors engaged in a struggle for identity and territory.

Civil society is perceived to be based on a normative tradition of enlightened selfinterest, justice, humanitarianism, and independence, while the second level, the interstate system, is based on a tradition of power-politics, competition and conflict in an environment made up of legally constituted sovereign states, which however, provide security, status and legitimacy to their dominant groups. At the third level, international society provides the philosophical framework for human security, despite the fact that it is torn by the tensions produced by statecentric interests, globalization and integration, and by the 'onerous' burden of humanitarianism. ${ }^{10}$ These three levels can be characterized in terms of the old distinction between a normative order and the order of power-politics. The order of power-politics became a system through the Westphalian imaginary in which sovereignty, territoriality and secularism became corner-stones of the international political structure and hence the international system of reciprocal recognition, enshrined in international law and in every peace treaty since Westphalia. Yet, with the elevation of intrinsic individual and human rights since the Enlightenment (though problematic in its universalism) and more particularly since the end of the Cold War, the international system of nation or national states ${ }^{11}$ has increasingly come into conflict with this notion-into conflict with itself. The first impulse of the analyst was to place Realpolitik above such rights in $\mathrm{IR}^{12}$ but the late twentieth century saw a shift from this position particularly as global and regional pressures have begun to push states into mutual co-operation. ${ }^{13}$ Even Carr recognized this in his famous attack on idealism. ${ }^{14}$ This can only continue, given the growing pressures on resources and on the environment, and the relative inability of states to impose themselves unilaterally in the contemporary world. This has led to debates about humanitarian intervention and the complexities over doing nothing, imposing universal values to end conflicts, and the sustainability of doing either.

9 See Ann Marie Clark, Elisabeth J. Friedman, and Kathryn Hochesteller, 'The Sovereign Limits of Global Civil Society: A Comparison of NGO Participation in UN World Conferences on the Environment, Human Rights, and Women', World Politics, 51: 1 (1998), pp. 3-4.

10 When the West responded against the Iraqi invasion of Kuwait in favour of Kuwait sovereignty and the subsequent crisis of the Kurdish population of northern Iraq emerged, the humanitarianism of the international community was faced with a serious challenge. The result was UN Security Council Resolution 688 of 5 April 1991 (see note 5 above). This resolution insisted that Iraq allowed humanitarian intervention to assist the Kurdish population. For the first time at the national level, the rule of law was not allowed to prevent humanitarian intervention. This humanitarian turn was partly made possible by a series of UN General Assembly resolutions which called for access for humanitarian assistance where it was required. See General Assembly Resolution 43/131, 8 December 1988; General Assembly Resolution 45/100, 14 December 1990; General Assembly Resolution 46/182, 19 December 1991.

11 A nation state theoretically incorporates one ethnic group, while a national state assimilates several into one group with an overarching identity.

12 The works of Hobbes and Machiavelli still provide a succinct characterization of this. Thomas Hobbes, Leviathan (Oxford: Oxford University Press, 1952): Niccolo Machiavelli, The Prince (New York: Penguin, 1984).

13 See Hedley Bull, The Anarchical Society: A Study of Order in World Politics (London; Macmillan, 1977); R.O. Keohane and J. Nye, Power and Interdependence (Boston, MA: Little, 1977).

14 E.H. Carr, The Twenty Years Crisis (London: Macmillan, 1966) [reprint], p. 5. 'Political science is the science not only of what is, but what ought to be'. Similar statements are repeated throughout the book. 
If we examine this three-level analysis ${ }^{15}$ then we can see that international and civil society levels are wrapped up in similar human security projects. Yet they may produce ethno-political tensions if these debates lead to, or prevent, fragmentation as a result of the attempted imposition of norms and values this entails, so eventually creating mono-ethnic rather than multiethnic states. Furthermore, the international system of sovereign states, though dominant because of its control of massive resources and legal access to the means of violence, appears to be increasingly anomalous because it depends on units with homogenous national identities in a territorially fixed and unchanging 'jig-saw puzzle' model. The state system, sandwiched in between the civil and the global, may exacerbate ethnic tensions via parochial elites' struggles for power and status in an environment in which identity has become more important than welfare, prosperity and co-existence, because of the notions of security that the international system entails. It is these notions of security that are perhaps more problematic than the direct challenges to majorities and sovereign actors which ethnic groups may mount. The institution of sovereignty is under question from those caught up in it yet not recognized by it. Hence the notion of ethnic sovereignty constitutes their attempt to find legitimacy, status, and security in the international system that will entail internal and external legitimacy. It is an extension of personal sovereignty, mirroring the sovereignty of units that call themselves states, and by similar criteria, but appealing to normative positions to provide ethnic sovereign actors with status and security. ${ }^{16}$ It is important to note that the logic of the Westphalian international system would seem to require that identity groups can find security through becoming sovereign in a national sense, and reproducing the logic of the nation state in an anarchic system. Devious objectives, ${ }^{17}$ the exploitation of negotiation, mediation, and other forms of diplomacy for objectives unrelated to the notion of compromise and concession, often arise as an unspoken compromise for ethnic groups between sovereignty and violence. If their claims do not receive recognition they may struggle interminably at bureaucratic, political, and practical levels in the hope that it accrues, as has occurred in the case of the (now) Palestinian Authority, and the unrecognized Turkish Republic of Northern Cyprus. If the ethnic group feels that no progress is being made they may

15 Note the differences between international society and the international system in the typology I am proposing. The international system is a product of the culture of high diplomacy, the security dilemma, and international anarchy, while international society is a product of the forces of globalization, global civil society and institutional humanitarian norm building beyond the state. There is a modicum of unity between the local and international society but much abrasion between them and the traditional interstate system. There is also the problem of arriving at an acceptable form of political community in the context of universal and particularist pressures. Andrew Linklater has noted that a post-Westphalian order, which he frames as dialogic, overcomes the obstruction that sovereignty, territoriality and citizenship has created for this 'universal communication community'which has important implications for identity issues in world politics. See Andrew Linklater, The Transformation of Political Community (University of South Carolina Press, 1998), p. 168.

16 As Frost has pointed out, the clash between state autonomy and individual rights, between sovereignty, human rights, intervention and self-determination is crucial in the contemporary international environment. Mervyn Frost, 'Ethics in IR at the Millennium', Review of International Studies, 24 (1998), p. 131.

17 See Oliver Richmond, 'Devious Objectives and the Disputants' Views of International Mediation: A Theoretical Framework', Journal of Peace Research, 35: 6 (1998). This refers to the exploitation of negotiation and mediation processes by disputants, who tend to defy the rational norms that this international system appears to assume. This tends to lead to long and drawn out negotiations in which disputants manoeuvre for indirect resources relating to legitimacy, and also re-arm. 
exploit forms of violence (organized or random, often aimed at civilian as well as military targets), as in the case of the Palestinians, the Kurds, in Kashmir, with the East Timorese or the Chechens, often of a high profile (dichotomous terrorist/ freedom fighter) nature.

While sovereignty has passed from Sovereign to recognized state-government in order to represent the interests of numerical majorities within many states, the focus of the struggle for diplomatic representation and identity has shifted to actors that find themselves excluded from contemporary Westphalian norms of sovereignty and national democratic governance. 'Cutting off the king's head' implies a more egalitarian distribution of the political resources of sovereignty at the inter-subjective level, and a rethinking of claims to sovereignty, bringing groups which were formerly disregarded, marginalized, or de-emphasized, into the emerging global system of political representation, resource distribution and development, and global meaning. Understanding the location of individuals in the context of the Westphalian international system requires a recognition that traditional forms of sovereignty locate individuals in a nation/national-state, which exists in a somewhat anarchical order; yet most of the world's population is now located in multi-ethnic states that are members of regional and global organizations, and all actors are susceptible to transnational norms and regimes, of a political, social, economic, ethical (or coercive nature). In many of these states the relationship between ethnic groups and territory is fraught by conflicting claims, between normative, historical, and strategic interpretations of territorial possession and rights of autonomy. Identity claims have gained new legitimacy; hence the emergence of ethnic sovereignty. Increasingly it is possible to discuss the acquisition of state sovereignty by certain groups such as the Kosovo Albanians and by the Palestinians, though not with the Kurds or the Chechens ${ }^{18}$ such inconsistencies may only increase the attempted replication of exclusionary forms of statehood by ethnic groups.

\section{The view from the international system}

It is like chaos theory... ${ }^{19}$

The UN Charter codified the norms of sovereignty and non-intervention that had emerged from the Westphalia system; this constitutes an important, though increasingly contested, part of the contemporary state system - together with the notion of

18 This is very dependent on the views of Western powers which have increasingly supported the former, but not the latter, mainly for inconsistent strategic and humanitarian reasons. This, perhaps, is why ethnic actors such as the Kurds pay so much attention to raising international awareness of their plight. However, the fact that Kurds of Northern Iraq have the protection of a no-fly zone can be interpreted as either a move towards greater independence and autonomy for them, or as an attempt by the international community to gain a reprieve on the longstanding debate about a Kurdish state in the region going back to the unratified Treaty of Sevres of 1921. See Treaty of Sevres, 1920, Articles 62, 63, 64. When the West responded against the Iraqi invasion of Kuwait in favour of Kuwait sovereignty and the subsequent crisis of the Kurdish population of northern Iraq emerged, the humanitarianism of the international community was faced with a serious challenge. The result was UN Security Council Resolution 688 of 5 April 1991 which, though passed on a narrow margin, brought human security to the fore, above that of state security for the first time.

19 Ramsbotham and Woodhouse, Humanitarian Intervention, p. 93. 
the 'Westphalian imaginary'. ${ }^{20}$ Since the Treaty of Westphalia in particular, the international system has been based on a legal model prescribing the sovereign equality of states in order to inject a level of 'society' into it. In line with critical and normative debates, the balance between enclosure and responsibility is increasingly in conflict in terms of human security rather than state security, the possibility of the irreversible collapse of the legitimacy of states and their ability to distribute welfare and security. At the same time, the legitimacy of other actors vis-à-vis states, and their ability to gain a reasonable level of welfare and security, has come to the fore. This has entailed a rethinking process that has provided an opportunity for ethnic claims for sovereignty to become creditable.

The Westphalian state has provided the somewhat tautological conceptual and epistemological conditions for sovereignty and recognition at the level of the traditional interstate system. ${ }^{21}$ As Held has argued, the development of the state system has seen an impetus towards the coincidence of territorial boundaries with a governance system; the introduction of standing armies; the creation of new mechanisms of law-making and enforcement; the centralization of administrative power; the alteration and extension of fiscal management; and the formalization of diplomacy and diplomatic institutions. ${ }^{22}$ Sovereignty offered a method of deciding the legitimacy of claims to power, ${ }^{23}$ and dictated that states are the highest form of political community and authority responsible for law-making, enforcement and settlement of disputes in the context of international law, which itself is oriented towards the creation of the minimum rules of coexistence. Though all states are equal before the law, conflicts between states are ultimately settled by force, and consequently the collective priority is the minimization of impediments to state action. ${ }^{24}$

Many ethnic actors, either leadership or grassroots actors, have mobilized according to these provisions with the hope of acquiring international status, as in the cases of the Tamils in Sri Lanka, Chechens, Turkish Cypriots, Armenians in Nagorno Kharabakh, Palestinians and Kurds which all established secessionist movements based upon the replication of nation-statehood. Consequently, states assume their claims to sovereignty are sacrosanct, seek to protect and promote their unity and cohesion, while ethnic groups seek to reproduce the logic of the national state to gain security, welfare, and legitimacy. This has tended to lead to an emphasis on security stemming from the attainment and creation of mono-ethnic units and provides ethnic actors with a powerful incentive to claim sovereignty, as statehood is perceived as the most advanced framework though which interests and needs can be

20 Article 2 (7) is particularly important here: 'Nothing contained in the present Charter shall authorize the United Nations to intervene in matters which are essentially within the domestic jurisdiction of any state or shall require the Members to submit such matters to settlement under the present Charter; but this principle shall not prejudice the application of enforcement measures under Chapter Vll'. See also the well-known argument of Benedict Anderson, Imagined Communities: Reflections of the Origins and Spread of Nationalism (Ithaca, NY: Cornell University Press, 1991).

21 The state as a person of international law should possess the following qualifications: (a) a permanent population; (b) a defined territory; (c) government; and (d) capacity to enter into relations with other states. See Article 1 of the Montevideo Convention on Rights and Duties of States, 1933, League of Nations Treaty Series 19. It should also be independent, have a degree of permanence, willingness to observe international law and respect for human rights. Ian Brownlie, Principles of Public

International Law (Oxford: Clarendon Press, 1990), pp. 72-9.

22 David Held, Democracy and the Global Order, p. 36.

23 Ibid., pp. 38-39.

24 Ibid., p. 78. 
pursued. It also provides state actors with a powerful incentive not to share power internally with ethnic actors which may in the future decide to secede, as this would risk a compromise of the state's (and its dominant interest groups') abilities to act. This tension was brought about because while the Treaty of Westphalia codified the principles and strategies of the secular state system, ${ }^{25}$ the Paris Peace conference after World War I established a contradictory doctrine of self-determination. This was only partially defused by the League's reconfirmation of the principle of territorial integrity in Article 10 of its Covenant, which gave priority to historically established state boundaries over the secessionist demands of minorities. ${ }^{26}$ Subsequently, during the Cold War era sovereignty and non-intervention was paramount. In the post-Cold War era a slight shift of emphasis towards human forms of security carries broad implications and repercussions. What has evolved is a set of clearly contradictory positions for states that contain more than one identity group making territorial claims beyond individual, democratic and minority rights. This has been partly responsible for ethnic conflict. Levels of security and legitimacy within pre-existing states have not been enough to prevent ethnic violence emerging nor tame internal ethnic 'security dilemmas', or prevent ethnic groups and minorities from perceiving their relationship with majorities and states as being inherently zerosum. Though sovereignty has increasingly been viewed as flawed for these reasons, ${ }^{27}$ ethnic groups tend to desire sovereignty despite potentially impinging on an existing state's claim to sovereignty in the process. This is the 'sovereignty trap'; the fear of disorder lurking beyond the statecentric order has meant that most actors, ethnic or national, have walked knowingly or unknowingly straight into this trap. Thus, for ethnic groups sovereignty is both their enemy, their saviour-liberator, and dictator.

This has led to a situation where states either assimilate, dominate, or promote an ideology of multiculturalism vis-à-vis minorities, and in return ethnic groups and minorities can accept assimilation, try to gain autonomy, or merely vocalize their difficulties. ${ }^{28}$ If multi-culturalism or assimilation fail, ethnic groups may decide on claiming sovereignty. Actors which control international recognition usually counter secessionist movements with all of the instruments of repression at their disposal, as exemplified by the responses of the Turkish, Iranian, and Iraqi governments to the episodic rebellions by the Kurds, and there is no framework through which the UN or other actors can counter ethnic claims to sovereignty, other than through minority rights regimes, or humanitarian intervention. ${ }^{29}$ Organizations like the OSCE, have found similar difficulties when it comes to broadening international frameworks to include the interests and the rights of non-state actors. ${ }^{30}$ Despite this, humanitarian intervention has increasingly been on the agenda, as the cases of Somalia, Bosnia, and Kosovo illustrated in the 1990s (and Rwanda emphatically underlined).

${ }^{25}$ See Oyvind Osterud, 'The Narrow Gate: Entry to the Club of Sovereignty States', Review of International Studies, 23 (1997), p. 170.

26 Michael E. Brown and Chantal de Jonge Oudraat, 'Internal Conflict and International Action', in Michael E. Brown, Owen R. Cote, Sean M. Lynne-Jones and Steven E. Miller, Nationalism and Ethnic Conflict (Cambridge: MIT Press, 1997), p. 174.

27 David Held, Democracy and the Global Order, p. 84.

28 Thomas Hylland Erikson, Ethnicity and Nationalism (London: Pluto Press, 1993), p. 124.

${ }^{29}$ Indeed the UN was a target for lobbying from Kurdish groups in the early 1970s to allow petitions from minorities.

30 The OSCE has, however, attempted to concentrate on developing a co-operative security system based on human rights, fundamental freedoms and the rule of law, market economies, and social justice. Lisbon Declaration, 3 December 1996. 
The tension between the international system and identity is therefore a core failing of the Westphalian international system and its attempts to promote 'order'. While some have argued that Article 1 of the UN Charter contained a promise of self-determination, Kelsen argued that it described relations among states, and that self-determination of peoples actually means the sovereignty of states: the principle of self-determination is thus basically a principle of non-intervention and respect for the claim of sovereign equality of UN member states. ${ }^{31}$ For example, the international community's ability to address the conflict in ex-Yugoslavia from 19911995 was stymied by the inherent contradiction between the right of national self determination claimed by ethnic minorities and national groups to legitimate their statehood, and the principle of territorial integrity. ${ }^{32}$ Here, the international community could have affirmed the moral and political superiority of human rights and democracy over territorial integrity and national self-determination. This would have required, as Burg has argued, that norms of human rights should therefore take priority over ethnic self-determination and that the principle of territorial integrity be subordinated to advancing democracy. ${ }^{33}$ While this appears to be plausible, the main problem would be to overcome the view of ethnic groups that sovereignty is the only final guarantee of their security. Furthermore, in the Westphalian framework, human rights are mainly the responsibility of states and their transnational organizations and institutions; democracy provides a safeguard of sorts, though ethnic minorities are far weaker than political minorities. Outside intervention in ethnic conflict, therefore, is fraught with difficulty as it is linked to changes in formal concepts of, and claims to, sovereignty associated with the traditional international system, to which even the increasing implementation of 'human rights enforcement ${ }^{34}$ in the early to mid 1990 s seemed to have fallen victim. Such forms of intervention are equally problematic as they tend to assume that sovereignty remains a potential barrier, and that its re-establishment or support is its goal-as was seen in Somalia from 1993-95. The justification of such intervention is also a normative problem for identity groups as it may threaten to replace physical insecurity with cultural and socioeconomic insecurity as was in evidence in the massive UN involvement in Cambodia to implement the terms of the Paris Peace Accords between 1991 and 1993.

The traditional international system is based on rigid segregation and the compartmentalization of territory (as well as the division of economic resources). Identity, culture, history and tradition are valued only if they strengthen national debates and provide a pool of loyal labour for defensive, military and economic purposes. It is this apparent undervaluing of local identities which provides the first major anomaly in the context of the emerging traditions of civil, regional and global norms. The second major anomaly is methodological in that the division of territory into selfsufficient or at least self-enforcing state projects tends to promote the division of populations into local identity groups, which given their differing access to resources, may suffer from historical, natural, or other forms of inequality. Thus, it

31 Christopher M. Ryan, 'Sovereignty, Intervention and the Law: A Tenuous Relationship of Competing Principles', Millennium: Journal of International Studies, 26: 1 (1997), p. 176.

32 Steven L. Burg, 'The International Community', in Milton Esman and Shirley Telhami (eds.), International Organisations and Ethnic Conflict (New York: Cornell University Press, 1995), p. 267.

33 Ibid., p. 268.

34 Robert Cooper and Mats Berdal, 'Outside Intervention in Ethnic Conflicts', Ibid., p. 182. 
is the international system which is an 'orrery of errors' 35 as the logic it provides actors cannot be successfully applied to all groups of actors, and only succeeds in creating the best-case of stability in a self-help system if certain specialized conditions are also met. It is these conditions that the traditional system has identified as being constants, which are actually in flux. The point here is that traditional notions of sovereignty provide states with security dilemmas, but the same logic can also be applied to identity groups within states or of a transborder nature. In effect, the ethnic security dilemma stems from the view that majorities may oppress minorities, which can therefore only find safety in ethno-politics and ethno-political alliances. ${ }^{36}$ The dilemma is that to separate may lead to violence, but not to separate may continue institutionalized oppression and structural violence. The extension of the ethnic security dilemma leads to the domino-effect proposition, or Balkanization, which all existing states fear. ${ }^{37}$

This is nowhere more apparent that in the areas which the collapse of the former Soviet Union left in transition, where the politics of identity became the main approach to political reorganization on a massive scale. These areas, often overlooked, exemplify much that remains problematic about the traditional view of the international system. ${ }^{38}$ This is also indicative of the failure of the traditional international system to deal with large scale change in the Middle East, the Mediterranean, Eastern Europe, and many post-colonial states, and the elevation of the expression of ethnic identity as a basic human right in response to the inability of states to provide or guarantee security and justice to such groups. Thus, the response of ethnic sovereignty on the part of oppressed ethnic groups that fear oppression.

Even in the so-called 'zones of peace' 39 the traditional international system is under pressure from regional interdependence and humanitarian norms purportedly of a global nature, as well as local pressure for greater regional accessibility and accountability. This may be described as the emergence of a post-conventional awareness in which a universal basis for the existence of political community may

35 Misquoted from R.K. Ashley, 'The Poverty of Neo-Realism', in Robert Keohane, Neo-realism and its Critics (New York: Columbia University Press, 1986), p. 258.

36 See Caroline A. Hartzell, 'Explaining the Stability of Negotiated Settlements to Intrastate Wars', in Journal of Conflict Resolution, 43: 1 (1999), pp. 4-6.

37 Recently, Britain seemed to embrace this, however, through the representative assemblies that were set up for Northern Ireland, Wales and Scotland, although this was also interpreted by some as a defence against complete separation.

38 See, for example, Rogers Brubaker, 'National Minorities, Nationalizing States, and External National Homelands in the New Europe (What Future for the State?)', Daedalus, 124: 2 (1995), p. 108. The '... massive nationalization of political space ... has left tens of millions of people outside "their own" national territory... Perhaps most spectacularly, some twenty-five million ethnic Russians have been transformed, by a dramatic shrinkage of political space, from a privileged national group, culturally and politically at home throughout the Soviet Union, into minorities of precarious status, disputed membership, and uncertain identity in a host of incipient, non-Russian nation-states. Many other groups in the region are similarly "mismatched", attached by formal citizenship to one state (in most cases a new- and nationalizing-state) and by ethnonational affinity to another. Among the more important are the three million ethnic Hungarians in Romania, Slovakia, Ukraine, and Serbia; the two million Albanians in Serbia, Montenegro, and Macedonia; the nearly two million Serbs living (before the war) in Croatia and Bosnia-Herzegovina; the nearly one million Turks in Bulgaria; the Armenians in Azerbaijan, especially in Nagorno-Karabakh; the Uzbeks in Tajikistan and the Tajiks in Uzbekistan; and the Poles in Lithuania and other Soviet successor states'.

39 Max Singer and Aaron Wildavsky, The Real World Order (New Jersey: Chatham House Publishers, 1993), p. 3. 
be attained. ${ }^{40}$ In 'zones of instability', by implication, a conventional awareness dominates, which has led to a dependence on the rationale of the state-system to overcome and to counteract the security dilemmas of which states and ethnic groups are the victim. The problem here is that the rationale of the state system operates at a level which does not reflect the full panoply of interactions and levels which have the potential and impetus to destabilize in the name of ethnic claims. Many states fall in between these zones. Cyprus is an example where the pressure for a postmodern state $^{41}$ in a regionalized environment has come into conflict with the pressures which traditional state behaviour and concerns replicate. Cyprus will be an important test case to see whether a post-conventional awareness will overcome the traditional, or whether the logic of the international system is still inscrutably of an exclusionary nature. Kosovo is also important in that the international community agreed that the integrity of Serbia is less important that the rights of the Albanians as an identity group. ${ }^{42}$ This has already occurred on the part of the British government vis-à-vis Northern Ireland, with an elaborate constitutional arrangement in which conflicting identities are somewhat assuaged by a flexible approach to sovereignty and governance (though as with all written agreements, the devil has proved to reside in the implementation). ${ }^{43}$ The turn of events in Kosovo, with the attainment of de facto status, and legitimacy as a negotiating partner for the Kosovo Albanians, indicated a level of organization, coherent objectives, directed by a unified and concerted community with a common objective; this placed pressure on the Serbs to accede to their demands which necessitated the exercising of their own sovereignty in order to protect it or make concessions. However, in the case of the Kurds, the lack of a co-ordinated civil society project, and the use of widespread terror tactics, led the international community into regarding their claim for an independent state of Kurdistan with suspicion; the no-fly zone ${ }^{44}$ in northern Iraq seemed to indicate that the international community is committed to human security for the Kurds in the region, but not to separate sovereignty; in Turkey, the international community has done little more than call on Turkey to respect human rights, regarding the Kurdish issue in south-east Turkey as a purely internal issue though some pressure for reform has been exerted through the EU. In the case of the Turkish Cypriot community in Cyprus, ethnic claims to sovereignty has been taken several steps further, and like the Palestinian authority, with the aid of

40 Andrew Linklater, 'The Achievements of Critical Theory', in Steve Smith, Ken Booth and Marysia Zalewski, International Theory: Positivism and Beyond (Cambridge: Cambridge University Press, 1996), p. 285.

41 For an elaboration of this see Georg Sorenson, 'An Analysis of Contemporary Statehood: Consequences for Conflict and Cooperation', Review of International Studies, 23 (1997), p. 255.

42 See, for example, 'Kosovo Talks Fail', Washington Post (23 March, 1999). The Kosovo Albanians signed a plan which would have give them autonomy for a three year interim period; the Serbs saw this as opening the door to secession. Similarly, the Greek Cypriots refuse to accept a confederal solution as they argue that the Turkish Cypriots would secede. In the case of Kosovo, the UN Secretary General reluctantly conceded that humanitarian ends may justify the use of force. Mark Weller, 'UN accepts that humanitarian ends justify military means', in The Times (25 March, 1999).

43 See 'Constitutional Issues', The Belfast Agreement, 1998. The text of the document can be found at http://www.incore.ulst.ac.uk/cds/agreements/belfast.html.

44 A recent article argued that the Kurds could perhaps be used against Saddam Hussein, but that one of the main problems for US policy was not to strengthen Kurdish opposition against Turkey. This is generally illustrative of the attitude of the international community where no mention was made of Kurdish claims to sovereignty. See 'Iraqi Kurds Wary of Attack', Washington Post (19 February, 1999). 
external sponsors or influence, they have established an autonomous entity which only lacks official recognition from the outside, mainly because its status is disputed or rejected by another state (the Republic of Cyprus in the case of the Turkish Cypriots, and Israel in the case of the Palestinians $\left.{ }^{45}\right) .{ }^{46}$ Similarly the break-up of the former Yugoslavia, and the Chechen war, has resulted in the establishment of actors with various claims to sovereignty. The long-running conflict over Kashmir between India and Pakistan tends to obscure the fact that there are indigenous groups within the territory that are making their own claims for sovereignty. The presence of Indian-backed communities in both Sri Lanka and Fiji (partly because of former British colonial policy) led to continual counter-claims for sovereignty which continue today despite the fact that regional dynamics may have changed. Such irredentist and secessionist movements aim for the recreation of sovereign units with homogenous identities plus viable territorial, political, and resource structures. In this world of scarcity, this seems to be a doomed movement leading down the trail of historical conflict and enmity over resources, identity, and even race, replicated by the sovereign discourse between states and ethnic groups. Such conflict easily becomes characterized by the appropriation of primeval myths of difference.

This means that the international system needs to find a way of mediating state claims to sovereignty with identity and human security. Most attempts to do exactly this have, however, almost inevitably handed authority for the implementation of such approaches to states, which are identified as responsible for protecting those rights. ${ }^{47}$ Consequently, the international system itself serves to exacerbate the perceptions of ethnic groups as to the inequalities of their situation within the state system, particularly when it comes either to a struggle on their part against oppression (often from a state), or on the part of ethnic entrepreneurs who also tend to reject the existing system.

Numerous UN resolutions related to the challenge of identity reveal the inherent dilemma in managing ethnic conflict and the tensions which exist between group rights and the perceived need for a stable international system. The Declaration on the Granting of Independence to Colonial Countries and Peoples states that all peoples have the right to self-determination, and calls for all armed action or repressive measures of all kinds directed against dependent peoples to cease in order to enable them to exercise peacefully and fully their right to complete independence. Yet it also makes clear that any attempt at the partial or total disruption of state sovereignty is incompatible with the purposes and principles of the UN Charter. ${ }^{48}$ Inherent in this

45 The Israelis have recently rejected the internationalization of Jerusalem, for example: The Times (17 March, 1999). In 1999, the idea was muted that a bridge should be built from the West Bank to Gaza in order to prevent any incursion upon Israeli sovereignty. Barak argued that the construction of a 47-kilometre bridge would allow safe passage for Palestinians.

46 The case of the 'TRNC' illustrates Clapham's point that quasi-states (such as the Venetian Republic and the Knights of St. John) are, and have been, generally part of the international landscape. Christopher Clapham, 'Degrees of Statehood', p. 144.

47 Ted Robert Gurr and Barbara Harff, Ethnic Conflict in World Politics (Oxford: Westview Press, 1994), p. 141.

48 UN General Assembly Resolution 1514 (XV), 14 December 1960. '7. All States shall observe faithfully and strictly the provisions of the Charter of the United Nations, the Universal Declaration of Human Rights and the present Declaration on the basis of equality, non-interference in the internal affairs of all States, and respect for the sovereign rights of all peoples and their territorial integrity'. See also Paul F. Diehl, International Peacekeeping (Baltimore, MD: John Hopkins University Press, 1993), p. 13. 
framework is an inability of the international community (as opposed to the international system) to accommodate conflicting claims for sovereignty over the same shared territorial space. Sovereignty's linkage with territory in a neatly compartmentalized system breaks down where sovereignty is linked with ethnic identity. ${ }^{49}$

It is the tension over whether ethnic actors will willingly allow states to assume the final responsibility for their status and rights that leads to ethnic claims for sovereignty, which becomes an extension of personal sovereignty, and in the absence of an umbrella organization in which personal and civil rights coincide, ethnic groups tend to create their own institutional framework. This can be seen as a reaction against the legal and political fragility of being assigned minority status, and a normative force for recognition of status and legitimacy. Thus, from the point of view of the international system, ethnic sovereignty is an anomaly caused by its own sovereign claims; from the point of view of states, it is a fundamental threat to their integrity and survival, and also to their claim to a sovereign monopoly on legitimacy.

\section{Ethnic groups and claims for sovereignty}

The expression of self-determination is derived from the principal of democratic equality and has been a somewhat vague notion incorporated into the international system since the League of Nations (although it was not specifically mentioned in the Covenant). ${ }^{50}$ The UN Charter does make specific reference ${ }^{51}$ to self-determination, though the principle was to be applied to non-self-governing territories. Since the process of decolonization gathered speed the principle has been stretched into new areas, as indicated by the gradual increase of legitimacy accrued by the Palestinians, for example. This has legitimized, at least in the eyes of ethnic groups, its progressive interpretation via a normative interpretation of the underpinnings of international community and a strategic vision of the workings of the international system. ${ }^{52}$

'Location' and 'sovereignty' constitute the key to ethnic survival; freedom from interference in a defensible territory is seen as vital to ensuring the survival of distinct communities. Consequently, what matters to an ethnie is the possession or association with a physical 'homeland'. ${ }^{53}$ The crucial forces creating and recreating ethnic identity are the geopolitical location of the community, religion, degree of autonomy, and degree of hostility it encounters, ${ }^{54}$ and the group may reinforce its internal legitimacy through grass roots or entrepreneur-led ethno-nationalism. The structure and concepts of the international system are utilized by ethnic actors to

49 States, not citizens, remain the fundamental rights and duty bearing units of the international community. Robert H. Jackson, 'The International Community Beyond the Cold War', in Gene M. Lyons and Michael Mastunduno, Beyond Westphalia (Johns Hopkins, 1995), p. 80.

50 Heather A Wilson, International Law and the Use of Force by National Liberation Movements (Oxford: Clarendon, 1988), p. 56.

51 See UN Charter, Articles 1(2) and 55.

52 Brownlie states that the principle of self-determination may justify the provision of a higher status to '...belligerent entities and exile governments than would otherwise be the case'. Ian Brownlie, Principles of Public International Law, p. 80.

53 Anthony D. Smith, The Ethnic Origin of Nations (Oxford: Blackwell, 1986), p. 93.

54 Ibid., p. 124. 
reconstruct their status in diplomatic language - therefore acceptable to states - that endeavours to provide the resources of statehood. Sovereignty itself becomes 'imagined', associated with identity from which rights are then derived, ${ }^{55}$ leading to a movement for self-determination. Thus, sovereignty becomes a package which ethnic groups exploit in the context of the 'Westphalian imaginary'. Ethnic actors are agents, though the claims of, and to, sovereignty come to redefine them - this may often provide the spark which intensifies ethnic awareness into conflict at the civil level. ${ }^{56}$ Sovereignty is supposed to represent the unity of identity, security, territory and power. Yet the incorporation of human rather than state security means ethnic groups may import 'international' concepts to a shared/ ambiguous political space from their imagined traditional international system, so leading to ethnic sovereignty.

Such groups seek self-determination for several reasons:

The urge for self-government may be motivated by a reaction against self-discrimination and humiliation, by the pragmatic expectation that the new nation-state will have greater economic and political freedom, by the wish to have a state in which different public policies would be pursued, by the desire for power and prestige amongst nationalist elites, or to protect a given ethnic culture from extinction ... Most importantly enthusiasm for the principle of self-determination flows from the democratisation of the world. ${ }^{57}$

Ethnic groups view sovereignty as providing their best prospects, yet have their own perceptions and version of what it entails. The general logic is that in the contemporary international system, all sovereign actors are perceived to have greater levels of security than non-sovereign actors, despite the examples provided by the states of Pakistan, Cyprus, Israel, Yugoslavia, Sri Lanka and many others, in which sovereignty was not a guarantee of external security or internal commitment. The sovereign assertion that territorial inviolability is paramount promotes territorial [ethno] nationalism. ${ }^{58}$

Conversely, ethnic groups tend to perceive sovereignty in its inflexible legalistic form, despite the fact that their actions may transgress this. In the contemporary environment, ethnic communities and their representatives must be able to prove that they have been discriminated against, perhaps violently by the majority, must

55 Benedict Anderson defined the nation as an imagined political community, inherently limited and sovereign. See Benedict Anderson, Imagined Communities, p. 7.

56 See, among others, Tarya Vayrynen 'Ethnopolitical Meaning in Global Conjunctions: Performative Politics', Paper Presented at the Third Pan-European International Relations Conference (Vienna , 16-19 Sept 1998), pp. 2-3.

57 McGarry, John and Brendan O'Leary. 'The Macro-Political Regulation of Ethnic Conflict', in John McGarry and Brendan O'Leary (eds.), The Politics of Ethnic Conflict Regulation (London: Routledge, 1993), p. 15. As the authors point out, majoritarian systems ' ...of liberal democratic government, designed to create strong powers for the governing party, is no guarantee of liberty for ethnic minorities. A 'winner takes all' system in the presence of ethnic parties ensures that ethnic competition will be regarded as zero-sum conflict... Unfortunately federalism has a poor track-record as an conflict regulating device in multi-ethnic states, even where it allows a degree of minority selfgovernment... Federal failures primary occur because minorities continue to be outnumbered at the federal level of government. Ibid., pp. 25-34.

58 In order to avoid the recreation of numerous mono-ethnic, nationalistic, entities driven by external security dilemmas it is necessary to promote a balance of autonomy and integration, universalism and particularism. See, for example, Richard Bellamy and Alex Warleigh, 'From An Ethics of Participation: Citizenship and the Future of the European Union', in Millennium: Ethics and International Relations, 27: 3 (1998), p. 448. They argue that a merging of cosmopolitanism and communitarism implies this. 
also be able to show that they have a coherent identity, territorial consistency and that there is very little choice other than sovereignty if they are to become secure and gain a level of equality with other actors in the local environment. Given that this will tend to be the perspective of ethnic groups that are either oppressed, or are being prompted by allies or sponsors in the local or regional environment, there is an opportunity for ethnic actors both to appeal to and exploit the principles which lie behind the notion of self-determination for their own zero-sum objectives. This blueprint of conditions required to create a viable claim for sovereignty and ethnic mobilization means that the ethnic group must have a coherent, monolithic voice in order to project plausible policies for separatism. It is at this point that ethnic entrepreneurs can step in to exploit the potential that autonomy provides for the community driven by ethnic perceptions of sovereignty and self-determination, as occurred in the Turkish Cypriot community of Cyprus after intercommunal fighting occurred in 1963. Identity politics thus becomes the prime area of discourse in an ethno-nationalist dialogue.

From this ethnic sovereignty emerges, based on normative and strategic perceptions of status. Claimants may accept the fact that international recognition is initially limited to mere procedural interaction with other members of the international community, as has been the case since the unilateral declaration of independence of the TRNC in 1983. But, many ethnic groups hold the hope that in future their status will be elevated, much in the same way that many colonial subjects after World War II believed that decolonization would result in unfettered sovereignty. From the perspective of ethnic groups ethnic sovereignty is seen as a precursor to a final legitimization and confirmation of their internal and external status, as has been the case with the Palestinian authority and their stated intention (first muted in 1988) to declare full sovereignty. ${ }^{59}$ It is a process of self-actualization in the context of the sovereign discourse of the contemporary international system. It is also possible that if this self-actualization does not receive external recognition, elements of the group may be tempted to use forms of low intensity violence such as terrorism in order to bring attention to their situation and apply pressure for change.

Yet, this means that sovereignty has become more stylized than practical. ${ }^{60}$ Because it was never envisaged that ethnic groups would become able to challenge states and their assimilationist nature, there was not perceived the need to incorporate other actors into the framework of the international system as the framework of governance of each state was able to do this to varying degrees, particularly if they were/are democracies. There is still the tendency amongst state actors to avoid giving power to non-state actors although this has seen an incremental erosion since the end of the Cold War. In Sri Lanka, Albania, Eastern Europe, Turkey, and Spain, for example, minority provisions and enhanced status may still not go far enough for more radical subgroups. Groups, such as the Kurds, still have to deal with

59 See statement by Yasser Arafat. Associated Press Release (19 December, 1998).

60 See J. Samuel Barkin, 'The Evolution of the Constitution of Sovereignty and the Emergence of Human Rights Norms', Millennium, 27: 2 (1998), pp. 229-231. Barkin argues that sovereignty is not in crisis as it is an adaptable concept which can incorporate human right norms. However, I would argue that this may well occur, but only because of the need to prevent inflexible forms of sovereignty leading to a breakdown of the international system. In others words, incorporation of humanitarian norms may occur by default. 
traditional assimilationist states that perceive them to be Trojan horses undermining national security in unstable regions where security is already fragile.

The focus of ethno-politics, as an increasing important vertical and horizontal segment of international politics, is on status and identity, leading to debates about secession, autonomy, or new political systems, and notions of legitimacy and equality are new key conditions. ${ }^{61}$ Sovereignty provides one of the most significant conceptual obstacles in that disputants see sovereignty as indivisible, according to the conventional Westphalia idea, ${ }^{62}$ but are forced to use violence to divide states and then recreate a mono-ethnic state of their own. Thus, in conditions where ethnic groups perceive their rights and existence are under threat they begin to organize resistance at social, political, and military levels, and as soon as they are able to influence (not necessarily dictate) the stability and order of a given state, they begin to accrue levels of ethnic sovereignty. Such developments are also driven by their own perceptions of the international system and the way in which actors are legally enabled to organize in order to gain security, legitimacy, and prosperity. Often they work within the grey areas of the international system to gain their objectives; often they may well exploit that system in order to accrue levels of sovereignty by exaggerating the threat they face and even manufacturing evidence. ${ }^{63}$ Ethnic sovereignty therefore is constituted by levels of political organization within an ethnic group, against existing states, with the objective of autonomy, secession, and separate statehood. ${ }^{64}$ It is often symbolized for the ethnic group by negotiations with the opposition, particularly if an international mediator (from the UN or another state) is involved; often therefore, 'ethnic negotiations' often degenerate into arguments over status or indirect political manoeuvres in order to attain/ confirm legitimacy. ${ }^{65}$ The contemporary trend amongst the international community of taking a humanitarian or normative view of identity conflict enables ethnic groups to simulate sovereignty. Often, of course, such systems are built on militarization, powerful and possibly irredentist sponsorship, isolation, poverty and an uncertain future, but such groups may still value their ethnic sovereignty more than entering the international community on the terms of accepting limited autonomy or minority status. ${ }^{66}$

61 I.William Zartman, 'Dynamics and Constraints in Negotiations in Internal Conflicts' in I.William Zartman (ed.), Elusive Peace (Washington DC; Brookings Institute, 1995), p. 15.

62 Alexis Heraclides, 'The Ending of Unending Conflicts; Separatist Wars', Millennium, $26: 3$ (1997), pp. 694-95.

63 For example in the case of the Turkish Cypriots, there is some, generally unsubstantiated, suspicion that some of the attacks against the Turkish Cypriot community in the 1960s were conducted by hard-line Turkish Cypriot groups in order to discredit the Greek Cypriot community.

${ }^{64}$ Given the shift in the norms associated with sovereignty since the emergence of the post-colonial state, and since the end of the Cold War, it is apparent that autonomy is as much as even many official sovereign actors can aspire to. This is regarded as negative sovereignty. See Christopher Clapham, 'Degrees of Statehoood', p. 146. However, some analysts disagree as under international law there can only be sovereignty or no sovereignty. See Thomas G. Weiss and Jarat Chopra, 'Sovereignty under Siege', in Gene M. Lyons, Beyond Westphalia, p. 99.

65 See for example, Oliver P. Richmond, Mediating in Cyprus (London: Frank Cass, 1998).

66 Increasingly though, as can be seen with the ethnic Albanians in Kosovo, the international community is willing to provide them with sufficient status to be able to negotiate future sovereignty; or in lesser form as with the Palestinians. But equally there are incidents where there is no real discussion of the international status of the group, as has been the case with the Kurds or the Basques. 


\section{The view from beyond the Westphalian system}

Are claims for ethnic sovereignty inevitable? The forces of regionalization and globalization accentuate the fragmentation brought about by ethnic groups' claims, prompting efforts to preserve their historical, cultural and other traditions. Yet it is also within the international community ${ }^{67}$ that a normative framework exists that offers ethnic groups both the hope of a broader, human, ethnic and cultural security, and a general recognition of the existence of a normative basis for such claims. Thus, a post-Westphalian international society, oriented around norms of human security and open discourses, may provide both the framework for the recognition of ethnic claims and the framework by which these claims emerge as viable - in the discourse of self-determination, human rights, basic freedoms and political equality. ${ }^{68}$ However, in the current rationalist international discourse ethnic groups may translate this dual recognition into claims for sovereignty, thus extending the international community into a position where its normative basis may undermine the basic foundations of the Westphalian international system-sovereignty and non-intervention. Potentially, ascribing sovereignty through recognition (as occurred during the collapse of the former Yugoslavia) could have become the UN's, ROs' or states' tool for providing human security to ethnic groups. ${ }^{69}$ Because of the fear of balkanization, it has led to the practice of peacemaking and peacekeeping in such cases becoming increasingly interventionary. Rationally speaking, the former would lead to a proliferation of both ethnic claims and states, while the latter has led to humanitarian intervention and its normative claims which makes international 'order' even more uncertain, selective, and contested.

Notwithstanding, this would seem to necessitate both a more flexible view of state claims to sovereignty and decisive measures to respond to the claims of ethnic groups before they become charged with the Westphalian discourses of national selfdetermination and state sovereignty. The shift to a more flexible view of sovereignty, which in itself may defuse the Pandora's box of ethnic conflict, may occur through the development of civil society in the context of regional and global norms of interdependence, democratization, human rights and welfare. Perhaps this would be along the lines of the dialogic community in a post-Westphalian international

67 For a discussion of international society and political community, see Chris Brown, 'The Idea of World Community', in Ken Booth and Steve Smith (ed.), International Relations Theory Today, (Cambridge: Polity Press, 1995); Hedley Bull, The Anarchical Society; R.J. Vincent, Human Rights and International Relations (Cambridge: Cambridge University Press, 1986).

68 For a discussion of the normative basis of a post-Westphalian international society, see Andrew Linklater, The Transformation of Political Community, p. 74.

69 As soon as one recognizes that states should be held accountable for their actions with respect to internal identity groups, the prospect of finding a new solution is raised, normally in the context of minority rights regimes, humanitarian law, and possibly even humanitarian intervention. This was aptly illustrated by the course of events during the dissolution of Yugoslavia, the secession of Slovenia and Croatia in June 1991 because of Serbian nationalism, the civil war in Croatia and then Bosnia Herzegovina leading to the latter's referendum confirming its desire for independence in March 1992. This was followed by its recognition by the then EC, and ultimately NATO intervention (to rescue a failing UN peace operation) against the Serbs over Bosnia, and later over Kosovo. In such cases, either a new solution is based on a mediated modification of the state or (often violent) attempts to create a new state. For a review of these events until late 1994, see Spyros Economides and Paul Taylor, 'Former Yugoslavia', in James Mayall (ed.), The New Interventionism 1991-1994 (Cambridge: Cambridge University Press, 1996), pp. 59-63. 
society, recently elucidated by Linklater. ${ }^{70}$ This proposes both a universal basis for such a community, which would present a firm foundation to address ethnic (and state) claims, but also for peacemaking and intervention to occur. However, while reciprocal state sovereignty forms the basis of world order, ${ }^{71}$ ethnic sovereignty may increasingly become legitimized from the perspective of ethnic actors on normative and strategic grounds, as ethnic violence against oppressive structures, and vice versa, continues. This repeats the continuity of one of the classic paradoxes of the international system that 'freedom' can only be won through violence.

Numerous examples illustrate the difficulties the international community has had in coming to terms with this problem. Perhaps it was this that influenced the UN Secretary General's statement that individual sovereignty must become recognized by the international community. ${ }^{72}$ However, UN pronouncements on the weakening of sovereignty are often followed by ringing endorsements, ${ }^{73}$ graphically illustrating the trap that neoliberal approaches fall into, when by attempting to 'enforce' humanitarian norms they come into conflict with the Westphalian foundations of that system assumed to produce order. This can also be clearly seen in the UN General Assembly Declaration on the Rights of Persons belonging to National or Ethnic, Religious and Linguistic Minorities. ${ }^{74}$ Article One states:

1. States shall protect the existence and the national or ethnic, cultural, religious, and linguistic identity of minorities within their respective territories, and shall encourage conditions for the promotion of that identity.

2. States shall adopt appropriate legislative and other measures to achieve those ends.

Yet Article Eight reaffirms the traditional norms of sovereignty:

4. Nothing in the present Declaration may be construed as permitting any activity contrary to the purposes and principles of the UN, including sovereignty equality, territorial integrity and political independence of States.

This resolution was reaffirmed by, among others, the Commission on Human Rights' resolution on Rights of Persons Belonging to National or Ethnic, Religious and Linguistic Minorities, in which the emphasis was again clearly placed on the role of states in guaranteeing minority rights. ${ }^{75}$ The case of the OSCE also illustrates this unresolved dilemma. The principles of the Helsinki Final Act of 1975 recognized human rights and collective rights of peoples for self determination (Principles $7 \& 8$ ),

70 Andrew Linklater, The Transformation of Political Community.

71 Barrie Axford, The Global System (Cambridge: Polity Press, 1995), p. 138.

72 See Kofi A. Annan, 'Two Concepts of Sovereignty', The Economist, 18 September 1999, and http://www.un.org/Overview/SG/kaecon.htm.

73 Agenda For Peace implied a far broader definition of security than had been hitherto common in the diplomatic arena, but also emphasized the ambiguity over a reduction of sovereignty and by extension, humanitarian intervention. See Boutros Boutros-Ghali, An Agenda For Peace: Preventative Diplomacy, Peacemaking and Peacekeeping (New York: United Nations, 1992), esp. pp. 5-22., para. 16. Paragraph 17 reiterates that the foundation stone of the organization remains the state and that the fragmentation of the state system must be curtailed.

74 UN General Assembly Resolution 47/135, 18 December 1992.

75 Commission on Human Rights Resolution, 1997/16. 
but principle 6 reaffirms the sanctity of sovereignty. Despite this, the OSCE has declared that on some occasions that sovereignty may give way to international intervention when basic human rights have been violated (although this is easily ignored as the OSCE has no funds, authority or forces). This has been apparent with the organization's role in ex-Yugoslavia and the then CSCE's initiative to inquire into human rights violations of Albanians in Kosovo. ${ }^{76}$ More recently, the OSCE peacekeeping mission in Nagorno-Karabakh was unable to deploy because the warring parties would not give their consent. ${ }^{77}$ The Lisbon Declaration states that there will not be support for those who are acting 'in violation of international law against the territorial integrity or political independence of any participating State'. ${ }^{78}$ Furthermore, the interests of the members of international organizations often result in the exclusion of ethnic conflicts from their agendas, as in the case of Tibet because of the Chinese veto in the Security Council, Corsica because of the French veto, and, until recently, East Timor because of Indonesia's connections with other states.

Normative expectations amongst members of the international community do seem to be shifting in favour of bypassing sovereignty when international peace and security are threatened, human rights are violated, and humanitarian disasters are created by ethnic conflict. The emergence of a contested global civil society constituted by non-state actors, loosely working to attain human security at the micro-level but also associating with states, the UN General Assembly, and with ROs would seem to indicate further developments here. It has been argued that it is at the level of the global and regional that preventative regimes may be institutionalized through transnational organizations and NGOs, which are able to contribute to the pacification of conflicts because the common bond of these organizations is their mission to enhance co-operation, to facilitate mutual understanding and to pacify the relations among their members, rather than focusing on the modalities of sovereign claims and relationships. As Adler has argued, the conditions for a community to develop are socially constructed - by the individuals, their state, and by international organizations which can help diffuse and internalize norms and knowledge about how to peacefully resolve conflicts. ${ }^{79}$ The creation of supranational and transnational communities may offset the development of ethnic sovereignty and the mono-ethnic entities that it threatens to breed, thus preventing the excesses of both ethnic sovereignty and state sovereignty. Yet, increasingly evidence is emerging to refute this. ${ }^{80}$

76 Milton Esman and Shirley Telhami, International Organisations and Ethnic Conflict, pp. 41-3.

77 SIPRI-UNESCO Handbook, Peace, Security and Conflict Prevention (Oxford: Oxford University Press), p. 53.

78 Lisbon Declaration, 3 December, 1996.

79 Emanuel Adler, 'Imagined Security Communities: Cognitive Regions in International Relations', p. 250 .

80 There are two main difficulties here. The first is that a common basis for treating identity and ethnic groups needs to be universally agreed. Any such agreement raises the difficulties of universal statements and intervention vis-à-vis culture and identity. As can be seen in the case of Cyprus, the role of the UN and more recently of the EU has not been able to bring the two communities together. In fact they have succeeded in reinforcing both sides' claims to sovereignty. See Oliver Richmond, 'Ethno-Nationalism, Sovereignty and Negotiating Positions in the Cyprus Conflict', Journal of Middle Eastern Studies, 35: 3 (1999). In the case of Palestinian sovereignty, this is still reliant upon their own claims, rather than mutual recognition. Indeed, the mutual recognition that the Oslo process entailed meant recognition of Israeli sovereignty by the Palestinians, and only of Palestinian autonomy by the Israelis. See D. Jones, Cosmopolitan Mediation (Manchester: University of Manchester Press, 1999), p. 5. 


\section{Conclusion}

All actors at all levels are involved in mediating their interests; sovereignty provides a flawed framework in which its dynamism as a mediating structure depends on actors' access to resources. Yet, sovereignty spans perceived claims that are of disputed legitimacy to legitimate control of undisputed territories. The legal definition of sovereignty is therefore a heavily stylized mediating structure derived from centuries of practice, from the biblical idea of the promised land ${ }^{81}$ countering European feudalism and leading to the mutual recognition structures required for the balance of power system to produce an order of sorts. As new actors have emerged with significant stakes in trans-boundary, trans-state, trans-national, regional and global interests, and the concurrent legitimization of local cultural, ethnic, and identity politics, the emerging system of world politics should reflect the new pressures that are arising. Both ethnic groups and states are caught between the sanctity of state claims to sovereignty and the sanctity of identity. In order to move away from post-colonial and Westphalian nation states, which tend to fail where multiethnic interest groups conflict, a transnational entity is needed. ${ }^{82}$ Such entities are unlikely to emerge if the international community does not come to terms with the anomalies caused by ethnic identity, ethnic disputants' lack of representation, and inherent contradictions in the international system. Unless the distinction between sovereignty vis-à-vis national groups and identity groups, and its differing ramifications for security and interdependence, are resolved, ethnic sovereignty, in which identity groups form visions of their own status, role and rights in the international system driven by ethnic responses to the perceived structural violence perpetrated by a system in which identity is overlooked or suppressed, may increase, echoing the binaries produced by state claims to sovereignty.

Ethnic sovereignty is derived from within ethnic groups themselves, rather than bestowed from the outside according to mandatory conditions. It is endorsed by implication by the humanitarian norms to which international society aspires. It is this to which the international community needs to respond in order to allow the expression of ethnic sovereignty as a legitimate, rather than a rebel, form of negative or quasi sovereignty, and one which can coexist with other claims legitimately, rather than compete illicitly. The days of absolute and exclusive sovereignty are indeed over, if they ever existed. ${ }^{83}$ As implied by their name, states are never completed entities - they are always in the process of becoming and not becoming. Rosenau's depiction of the shift from Cold War to post-Cold War eras as 'bifurcation of world politics' between a sovereignty-bound world to a sovereignty-free world ${ }^{84}$ misses the point in that a self-constructed 'web of meaning', of which perceptions of

81 This idea was introduced by Costas Constantinou, 'The State as Sedition', ISA-ECPR Joint Convention, Vienna, 16-19 September, 1998.

82 Georg Sorenson, 'An Analysis of Contemporary Statehood: Consequences for Conflict and Cooperation'. See also Oliver P. Richmond, 'Mediating Ethnic Conflict: A Task for Sisyphus?', Global Society, 13: 2 (1999); John Chipman, 'Managing the Politics of Parochialism', in Michael E. Brown (eds.), Ethnic Conflict and International Security, pp. 245-55.

83 Boutros Boutros Ghali, An Agenda for Peace, p. 9.

84 J. Rosenau, Turbulence in World Politics: A Theory of Change and Continuity (Princeton, NJ: Princeton University Press, 1990), p. 10. 
sovereignty are an important part, partially defines actors' objectives. ${ }^{85}$ It is this that claims of sovereignty represent from the point of view of ethnic groups.

Ethnic sovereignty can be defined as a form of status accrued from internal and sometimes external sources, and derived from reorganization along the lines of a state project. It arises even as ethnic groups are under pressure from host states, and even though the international system dictates the inadmissibility of such claims. The international community, on the other hand, may be less adamantly against conceding legitimacy and sovereignty, though in the majority of cases it now calls for autonomy and increased safeguards. Subsequently, however, such statements tend to be exploited by ethnic groups to develop a framework for a case for the legitimacy of both its objectives and its status, both for the benefit of internal actors and the international community. Ethnic sovereignty therefore emerges through the logic of the international system and its replication at a communal level, based on a popular view of self-determination, the desire for human security, and the 'guarantees' engendered in the attainment of sovereignty. It can take the form of actual and de facto control over territory, the formation of local administrations, or even administrations in exile. For ethnic groups it holds out their only hope that the international system can provide at least a theoretical framework for their security and future well-being, is derived therefore from the ethnic groups' perception of how the international system operates, and also from the normative and ethical themes that underpin the problematic but accepted integral principle of self-determination. Yet, as the case of the collapse of former Yugoslavia aptly illustrated, the recognition of such claims to sovereignty often result in heightened insecurity. As occurred in East Timor after the referendum in 1999, even the recognition of the possibility of separation can lead to violence. Thus, given the emergence of ethnic claims for sovereignty it has become important that smaller, homogenous, political units become viable and integrated parts of an international system that preserves civil values and identity and avoids the binary replication of the enclosure which the concept of the nation/national state encourages with respect to identity. When ethnic actors begin to organize along these lines, they are already becoming dangerously 'sovereign' in its most exclusionary sense.

There is an obvious approach to this problem, which is to reject all absolute claims to sovereignty. ${ }^{86}$ To a certain extent this has already occurred in post-colonial states which had their constitutions created by outside actors, states that are subject to the demands of international treaties, or rely on peacekeeping, peacemaking or peacebuilding, or the support of international organizations and institutions. Yet many such states do not recognize these interpretations of their sovereignty in practice because of fears of additional territorial claims by other actors.

Given that claims to sovereignty still form the basis for much of world order, the king's head remains, if a little shaken by, among other things, the emergence of ethnic sovereignty. However, sovereign claims produce their own dilemmas both for ethnic groups and states, and pits them against each other in the context of an

85 M. Neufeld, 'Interpretation and the "Science" of International Relations', Review of International Studies, 19: 1.

86 Clapham argues that in-between stages could be accepted; this may just reproduce this binary however, as there will still be an elevated position where actors could make absolute claims, where security is perceived to be greater. See Christopher Clapham, Degrees of Sovereigny, p. 143. 
international system which promotes a myth of absolute state sovereignty as the guarantee of security, independence and legitimacy, but ultimately selectively provides neither. This may lead to the creation and recreation of bounded mono-ethnic and non-pluralist entities, ironically founded on liberal humanitarian norms, reproducing the sovereign discourse of state-centricity and using parochial identities as the starting point for a new practice of exclusion. 